\title{
Temporal dynamics and management of downy mildew on the table grape 'BRS Vitória' in northern Paraná
}

\author{
Dinâmica temporal e manejo do míldio na uva de mesa 'BRS \\ Vitória' no norte do Paraná
}

\author{
Carolina Bertuzzi Pereira ${ }^{1 *}$; Dauri José Tessmann²; \\ Rosangela Getirana Santana ${ }^{3}$; Rodrigo Iván Contreras-Soto ${ }^{4}$; \\ Reginaldo Teodoro de Souza ${ }^{5}$; Rosemeire de Lellis Naves ${ }^{5}$
}

\begin{abstract}
Downy mildew caused by Plasmopara viticola is a major disease of grapes in Paraná State, Brazil and other wine-producing regions. The seedless table grape 'BRS Vitória' stands out for its tolerance to this disease and is a viable alternative to reduce fungicide applications. The objectives of this study were to analyze the influence of weather-related factors, such as temperature and rainfall on disease progress and to evaluate the efficacy of fungicide spray programs for controlling downy mildew of grapes during the summer-fall and winter-spring crop seasons in northern Paraná, Brazil. Field trials were conducted in Marialva, Paraná, during the winter-spring crop seasons (August to December) in 2013 and 2014 and the summer-fall crop seasons (January to May) in 2014 and 2015. The experimental design used was completely randomized with repeated measurements over the phenological periods, with five treatments and 10 replicates. The following treatments were compared: (1) conventional, in which fungicides were applied according to conventional standards; (2) preventive fungicide sprays every seven days; (3) preventive fungicide sprays every 14 days; (4) fungicide sprays after observing the first downy mildew symptoms; and (5) no fungicide sprays. In the conventional fungicide program, sprays were performed two or three times per week. Treatments 2 and 3 received sprayings between the start of branch budding and fruit ripening. In treatment 4, sprays started from the first occurrence of oil spot symptoms, and then, the applications were spaced every seven days until fruit ripening. The severity of disease was evaluated weekly. The disease was severe only in the 2014 and 2015 summerfall crop seasons, reaching a maximum severity of $17.3 \%$ and $21.3 \%$ of the leaf area, respectively. The highest disease severity in the summer-fall crop seasons was associated with higher frequencies of rainy days and higher temperatures. Disease severity in conventional treatments did not differ from severity in treatments with sprayings made every seven and 14 days during the summer-fall crops in both years. Severity index on bunches were not observed for the evaluated trials. The seedless grape 'BRS Vitória' is less dependent on the use of fungicides to control downy mildew in northern Paraná.
\end{abstract}

Key words: Control. Epidemiology. Plasmopara viticola. Vitis vinifera.

${ }^{1}$ Discente, Curso de Doutorado, Programa de Pós-Graduação em Agronomia, Proteção Vegetal, Universidade Estadual de Maringá, UEM, Maringá, PR, Brasil. E-mail: carol_bertuzzi@hotmail.com

2 Prof. Dr., Departamento de Ciências Agrárias, UEM, Maringá, PR, Brasil. E-mail: djtessmann@gmail.com

${ }^{3}$ Prof $^{a}$ Dr $^{\text {a }}$, Departamento de Estatística, UEM, Maringá, PR, Brasil. E-mail: rgsantana@uem.br

${ }^{4}$ Prof. Dr. e Pesquisador, Instituto de Ciências Agronômicas, Universidad de O’Higgins, UOH, Rancagua, Chile e Centro de Estudios Avanzados en Fruticultura, CEAF, Rengo, Chile. E-mail: contrerasudec@gmail.com

5 Pesquisadores, Empresa Brasileira de Pesquisa Agropecuária, EMBRAPA Uva e Vinho, Estação Experimental de Viticultura Tropical, Jales, SP, Brasil. E-mail: reginaldo.souza@embrapa.br; rosemeire.naves@embrapa.br

* Author for correspondence 


\section{Resumo}

O míldio da videira causado pelo fungo Plasmopara viticola é a principal doença da videira no Paraná e em outras regiões vitícolas do país. A cultivar de uva sem sementes BRS Vitória destaca-se pela tolerância a esta doença e constitui uma alternativa viável para a produção de uva de mesa com menor emprego de fungicidas. Os objetivos deste trabalho foram analisar a influência de fatores climáticos sobre o progresso da doença e avaliar a eficácia dos programas de pulverização de fungicidas para controlar o míldio da videira durante as safras normal e temporã no norte do Paraná, Brasil. Os ensaios de campo foram conduzidos em Marialva, Paraná, durante as safras normal (agosto a dezembro) em 2013 e 2014 e safra temporã (janeiro a maio) em 2014 e 2015. O delineamento experimental utilizado foi inteiramente casualizado com medidas repetidas ao longo dos períodos fenológicos, com cinco tratamentos e 10 repetições. Os seguintes tratamentos foram comparados: (1) convencional, em que os fungicidas foram aplicados de acordo com padrões convencionais; (2) pulverizações a cada sete dias; (3) pulverizações a cada 14 dias; (4) pulverizações de fungicidas após observar os primeiros sintomas do míldio; e (5) controle. No programa convencional, as pulverizações foram realizadas duas ou três vezes por semana. Os tratamentos 2 e 3 receberam pulverizações entre o início da brotação e a maturação do fruto. No tratamento 4, as pulverizações começaram a partir da primeira ocorrência de sintomas de manchas de óleo e, em seguida, as aplicações foram espaçadas a cada sete dias até a maturação dos frutos. A severidade da doença foi avaliada semanalmente. A doença ocorreu apenas nas safras de verão e outono de 2014 e 2015, atingindo uma severidade máxima de 17,3\% e 21,3\% da área foliar, respectivamente. A maior severidade da doença nas safras temporãs foi associada a frequências mais altas de dias chuvosos e temperaturas mais altas. A severidade da doença nos tratamentos convencionais não diferiu da severidade nos tratamentos com as pulverizações a cada sete e 14 dias durante as colheitas das safras temporãs de ambos os anos. Não foram observados índices de severidade em cachos para os ensaios avaliados. A uva sem sementes 'BRS Vitória' é menos dependente do uso de fungicidas para controlar o míldio no norte do Paraná.

Palavras-chave: Controle. Epidemiologia. Plasmopara viticola. Vitis vinifera.

\section{Introduction}

The northern region of Paraná stands out for its table grape production, and it is responsible for approximately $20 \%$ of the total grapevine growing area in Brazil (KISHINO et al., 2007; SHIMANO; SENTELHAS, 2013). This region is characterized by two crops per year, referred to as winter-spring and summer-fall crop seasons (KISHINO et al., 2007). In the winter-spring crop season, winter pruning is carried out at the end of winter in July and early August, with the harvest in December. In the summer-fall crop season, summer pruning occurs after the harvest that originated from winter pruning, resulting in production between May and June (ANZANELLO et al., 2010).

Downy mildew, caused by the oomycete Plasmopara viticola, is the most important disease affecting grapevines in northern Paraná, and outbreaks occur during periods of high temperatures and relative humidity with extended hours of leaf wetness in the summer-fall crop season. This disease is highly destructive, affecting all green tissues of the plant, including leaves, young shoots, inflorescences, and grape bunches, and it results in losses of up to $100 \%$ of table grapes (TESSMANN et al., 2007).

Disease management relies heavily on chemical control, because table grape cultivars traditionally grown in northern Paraná and around the country are highly susceptible to downy mildew. Most of these chemical control applications are preventive, aiming to mitigate the risk of damage from the disease. These preventative applications cause an increase in the cost of production and negative impacts on the health of producers, grape consumers and the environment (KISHINO et al., 2007; TESSMANN et al., 2007).

Thus, the development of table grape cultivars that are more tolerant to downy mildew and that require less use of fungicides is important for 
social, economic and environmental sustainability of viticulture in Brazil. The seedless cultivar, 'BRS Vitória', resulted from crossing CNPUV 681-29 x 'BRS Linda' and was developed by the Embrapa Grape and Wine Tropical Viticulture Experimental Station in Jales, SP. This cultivar is a novelty that has several features satisfying the new requirements for the consumer market, as it is seedless and more tolerant to downy mildew. 'BRS Vitória' is an important advance over other seedless grape cultivars available because of its potential to reduce the number of fungicide applications to control downy mildew (MAIA et al., 2014). Nevertheless, the behavior of 'BRS Vitória' table seedless grape under the influence of the climatic conditions and spray programs in Northern Paraná State is unknown in terms of the impact on the occurrence of downy mildew.

In this context, the objectives were to analyze the influence of weather-related factors, such as temperature and rainfall on disease progress and to evaluate the efficacy of fungicide spray programs for controlling downy mildew of grapes during the summer-fall and winter-spring crop seasons in northern Paraná, Brazil.

\section{Material and Methods}

The trials were carried out in a commercial vineyard of 'BRS Vitória' seedless table grape during four consecutives crop seasons: winter-spring crop seasons in 2013 and 2014 and summer-fall crop seasons in 2014 and 2015. The experimental area was located in Marialva, Paraná (Lat 23²9’06 “S, 5147’30 Long." and alt 602 m.). According to the Köppen classification, the climate is Cfa, a mesothermal climate with an average temperature in the warmest month above $22^{\circ} \mathrm{C}$, and average temperature in the coldest month is below $18^{\circ} \mathrm{C}$ (CAVIGLIONE et al., 2000).

The cultivar 'BRS Vitória' from 2-year-old vines grafted on 'IAC 766 Campinas' rootstock was trained on an overhead trellis with spacing of $5.0 \mathrm{~m}$ between plants and $2.5 \mathrm{~m}$ between rows. The plot size was $50 \mathrm{~m}^{2}$ with a useful area of $18 \mathrm{~m}^{2}$. Each plot consisted of four plants.

In the winter-spring crop season, the branches were pruned on 08/05/2013 and 08/04/2014, and the fruits were harvested on 12/05/2013 and $12 / 04 / 2014$, respectively. In the summer-fall crop season, the branches were pruned on 01/22/2014 and $01 / 21 / 2015$, and the fruits were harvested on $05 / 14 / 2014$ and $05 / 20 / 2015$, respectively. The budding of the branches was stimulated chemically with hydrogen cyanamide at 4\%. Per branch, 1-2 buds were pruned. Shoot topping was done with 16 to 20 leaves. The branches were tied twice to improve their distribution in the vineyard. The harvest was performed when bunches of grapes showed soluble solids higher than $18^{\circ}$ Brix.

The experiments were arranged in a completely randomized design with repeated measurements over the phenological periods, with five treatments and 10 replicates. The following treatments were compared: (1) conventional, in which fungicides were applied according to conventional standards; (2) preventive fungicide sprays every seven days; (3) preventive fungicide spray every 14 days; (4) fungicide spraying after observing the first downy mildew symptoms; and (5) no fungicide sprays (Table 1). In the conventional fungicide program, sprays were performed two or three times per week. Treatments 2 and 3 received sprayings in the period between the start of branch budding and fruit ripening. In treatment 4 , sprays started at the occurrence of oil spot symptoms, and then the applications were spaced every seven days until fruit ripening. The volume of water used in fungicide spray was $800 \mathrm{~L}$ per ha. To minimize drift, applications were made in the absence of wind, and as usual for overhead trellises, the jet was directed from below, leaving a border of $70 \mathrm{~cm}$ on each side of the plot.

The severity of disease was evaluated weekly during three phenological periods (flowering to fruit set; fruit set to beginning of ripening; beginning of 
ripening to harvest). Initially, 10 branches were marked by treatment in the useful area of the plot, each branch with 20 leaves. The severity was estimated by the percentage of diseased leaf area using the scale developed by Buffara et al. (2014).
The severity index was determined using the McKinney (1923) index formula as follows: SEV $=[\Sigma$ (disease rating $\mathrm{x}$ number of plants with this rating)/ (the highest rating $x$ total number of plants counted)] x 100 .

Table 1. Treatments, active ingredients and doses of fungicides used for the control of downy mildew in table grape cv. BRS Vitória in Marialva, Paraná.

\begin{tabular}{|c|c|c|}
\hline Treatments & Active ingredient & Dose $\left({\left.\mathrm{g} 100 \mathrm{~L}^{-1}\right)}^{2}\right.$ \\
\hline Conventionalh & Cymoxanil + Mancozeb & $20+160$ \\
\hline \multirow[t]{8}{*}{ (spray performed two or three times per week) } & Propineb & 210 \\
\hline & Benalaxyl + Mancozeb & 146 \\
\hline & Fenamidone + Propineb & $15+210$ \\
\hline & Difenoconazole & $2-3$ \\
\hline & Dimethomorph & $450-675$ \\
\hline & Metiram + Pyraclostrobin & $10+110$ \\
\hline & Copper oxychloride & $180-210$ \\
\hline & Thiophanate methyl & 49 \\
\hline \multirow[t]{5}{*}{ Spray every seven days } & Thiophanate methyl + Propineb & $50-63+210$ \\
\hline & Cymoxanil + Mancozeb & $20+160$ \\
\hline & Metiram + Pyraclostrobin & $10+110$ \\
\hline & Benalaxyl + Mancozeb & 146 \\
\hline & Dimethomorph & $450-675$ \\
\hline \multirow[t]{3}{*}{ Spray every 14 days } & Benalaxyl + Mancozeb & 146 \\
\hline & Cymoxanil + Mancozeb & $20+160$ \\
\hline & Dimethomorph & $450-675$ \\
\hline & Benalaxyl + Mancozeb & 146 \\
\hline \multirow{2}{*}{ of the first symptoms of downy mildew } & Cymoxanil + Mancozeb & $20+160$ \\
\hline & Dimethomorph & $450-675$ \\
\hline
\end{tabular}

Descriptive statistics were used to describe the maximum severity of disease and severity index to the bunches of the cultivar 'BRS Vitória' before fruit harvest. Sixty bunches were evaluated, taken at random in the center of each plot, that were considered suitable for market as they did not show symptoms of downy mildew.

The disease severity scores showed an excess of zeros, overdispersion and non-normal distribution; thus, a generalized linear mixed model (GLMM) approach, assuming a beta distribution (random component) with the logit link function, was used. For modeling purposes, severity scores were divided by 100 and added to a constant (0.00001), considering that a beta probability distribution represents proportions higher than zero. The incorporation of the plot as a random effect is an appropriate way to consider the lack of independence between the observations of the same plot, as observations are performed repeatedly over time. Severity data for three phenological periods were adjusted by the model:

$$
\eta_{i j k}=\log \left(\frac{\pi_{i j k}}{1-\pi_{i j k}}\right)=\beta_{0}+C_{i}+T_{j}+(C T)_{i j}+R_{k(i)}
$$

where $\pi_{\mathrm{ijk}}$ is the probability that a plant shows symptoms of downy mildew in $\mathrm{k}$ repetitions of treatment $i$ and phenological period $j, \beta_{0}$ is the overall average, $\mathrm{C}_{\mathrm{i}}$ is the treatment effect (fixed effect), $T_{j}$ is the phenological effect (fixed effect), 
$\mathrm{CT}_{\mathrm{ij}}$ is the interaction effect between the treatment and phenological period and $\mathrm{R}_{\mathrm{k}(\mathrm{i})}$ is the random effect due to repetition (branch) of treatment. Generalized Pearson's chi square/DF and residual analyses were used to evaluate the fit of the model for severity. A Type III analysis was conducted to evaluate the statistical significance of the main and interaction effects in the models of treatments and phenological periods. Mean comparisons were performed with contrasts in PROC GLIMMIX of Statistical Analysis System version 9.4 (SAS INSTITUTE, 2003).

Daily measurements of minimum and maximum air temperature $\left({ }^{\circ} \mathrm{C}\right)$ and rainfall $(\mathrm{mm})$ were recorded by a micrometeorological station ( $\mu$ METOS, MCR200 model) located inside the vineyard. In order not to split the nighttime, the days were considered to begin at 12:00 and end at 12:00 the next day.

\section{Results and Discussion}

Downy mildew epidemics did not occur in the winter-spring crop seasons of 2013 and 2014. However, in the summer-fall crop seasons of 2014 and 2015 , the disease reached a maximum severity of $17.3 \%$ and $21.3 \%$ on the leaves, respectively (Table 2). The first symptoms of downy mildew were observed on 25/February (33 days after pruning) and 20/February (30 days after pruning) in the summerfall crop seasons of 2014 and 2015, respectively. The plants were flowering, corresponding to stage 19 on the scale of Eichhorn and Lorenz described by Pratt (1988).

Table 2. Number of sprays; maximum severity of downy mildew and severity index of downy mildew (\%) of table grape cv. BRS Vitória conducted under different fungicide programs in Marialva, Paraná. Summer-fall crop seasons (January to May) in 2014 and 2015.

\begin{tabular}{lcccccc}
\hline \multicolumn{1}{c}{ Treatments } & \multicolumn{2}{c}{$\mathrm{N}^{\mathbf{c}}$ of Sprays $^{2}$} & \multicolumn{2}{c}{ Maximum severity in leaves (\%) } & \multicolumn{2}{c}{ Severity index on bunches (\%) } \\
\hline & 2014 & 2015 & 2014 & 2015 & 2014 & 2015 \\
\hline CONV & 28 & 32 & $0 \pm 0$ & $6.2 \pm 6.9^{3}$ & 0 & 0 \\
S+7 & 12 & 12 & $1.3 \pm 2.8$ & $8.5 \pm 6.4$ & 0 & 0 \\
S+14 & 6 & 6 & $2.6 \pm 4.2$ & $10.0 \pm 9.8$ & 0 & 0 \\
S_O & 4 & 4 & $11.2 \pm 5.5$ & $17.7 \pm 9.9$ & 0 & 0 \\
CONTROL & 0 & 0 & $17.3 \pm 16.4$ & $21.3 \pm 7.7$ & 0 & 0 \\
\hline
\end{tabular}

${ }^{\mathrm{i}} \mathrm{CONV}=$ conventional; $\mathrm{S}+7=$ spray every seven days; $\mathrm{S}+14=$ spray every 14 days and $\mathrm{S} \_\mathrm{O}=$ spraying after observation of the first downy mildew symptoms.

${ }^{2}$ Number of chemical fungicides sprayed to control downy mildew, according to the programs described in Table 1 .

${ }^{3}$ Means and standard deviation.

In the summer-fall crop seasons of 2014 and 2015, 60.4\% (272 leaves) and 44.2\% (199 leaves) of leaves, respectively, were recorded as undamaged (Figure 1), and the null results (excess of zeros) observed in the assessments of severity could be considered an additional evidence demonstrating the tolerance of the seedless table grape against downy mildew. Therefore, it was necessary to propose a mathematical model to analyze disease progress as a function of time. Goodness-of-fit statistics showed that the generalized chi-square of Pearson/DF equals approximately one, and the residual analyses provided a check of the model's goodness-of-fit. Data must be close to the progress curve to describe what it is happening to ensure that decisions are carried out reliably.

Furthermore, the disease severity evaluated in 2014 and 2015 (summer-fall crop seasons) showed that treatment effects were significant $(p \leq 0.05)$ in both years, and the phenological effect was only significant in 2015. However, the interaction between phenological periods and treatments was not significant $(\mathrm{p}>0.05)$ in both years. Consequently, 
treatment and phenological effects on severity were separately studied (Table 3). The most susceptible stage to downy mildew covers the period between branch shooting to the stage of "grand-pea" (PEARSON; GOHEEN, 1988; SÔNEGO, 1998).
In this study, during the summer-fall crop season of 2015, the comparison between phenological periods showed that the maximum levels of severity were recorded prior to the beginning of ripening (Table 4, Figure 2b).

Figure 1. Percentage of leaf area damaged by downy mildew in table grape cv. BRS Vitória during 2014 (a) and 2015 (b) growing seasons in Marialva, Paraná.
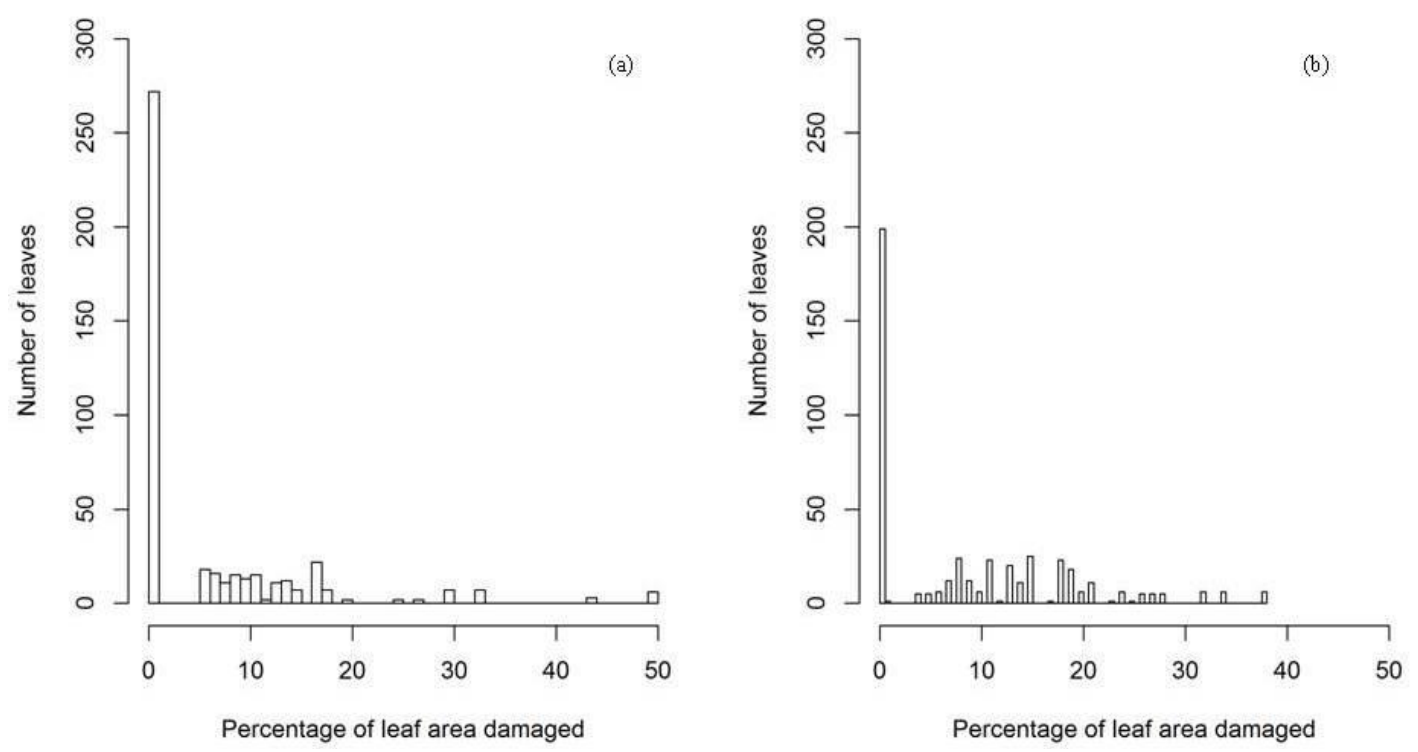

Figure 2. Downy mildew disease progress curve in table grape cv. BRS Vitória during 2014 (a) and 2015 (b) growing seasons in Marialva, Paraná. FL-FS = Flowering to fruit set; FS-BR = Fruit set to beginning of ripening; BR-HA= Beginning of ripening to harvest.
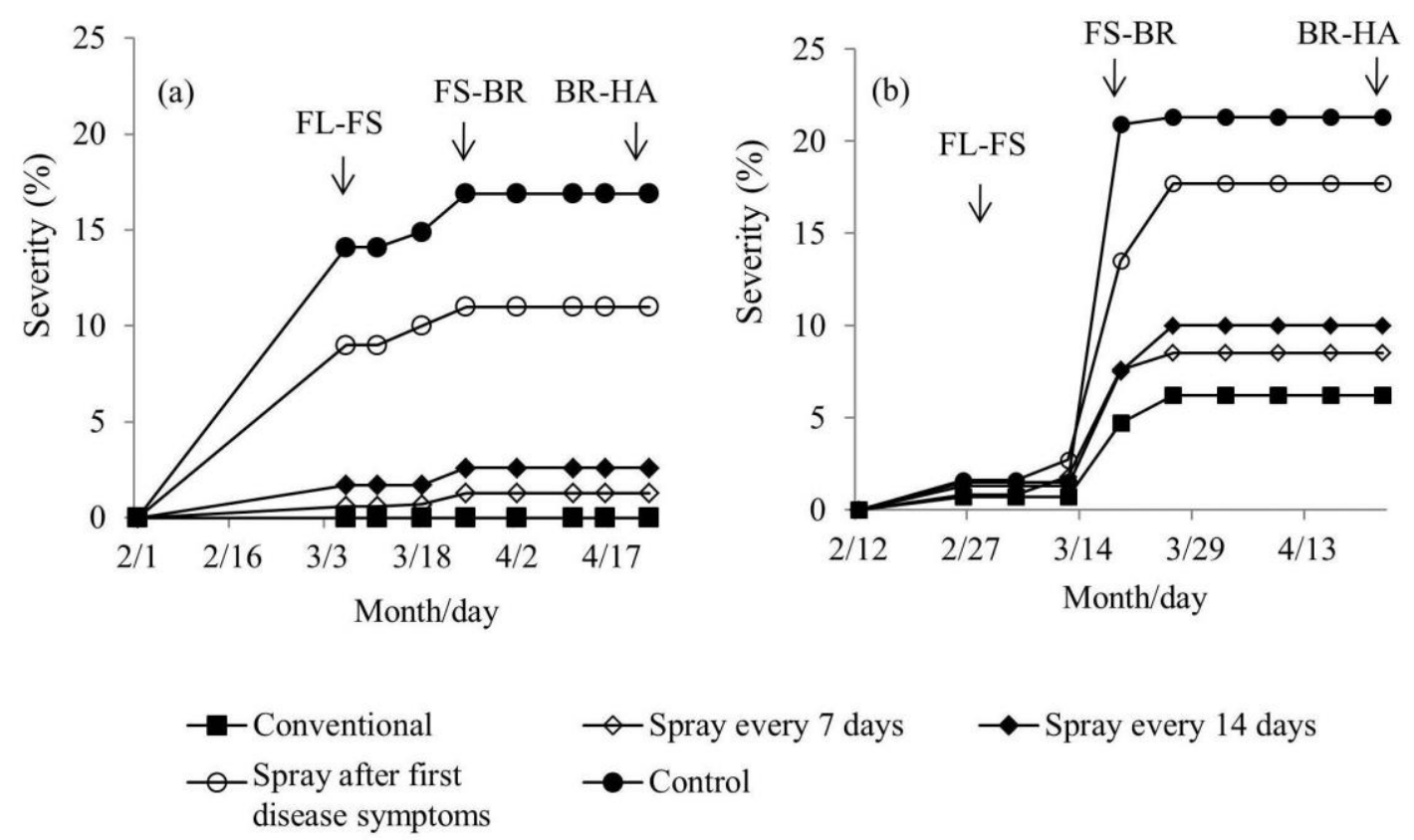
Table 3. Type III analysis for fixed effects.

\begin{tabular}{lcccc}
\hline \multirow{2}{*}{ Sources of variation } & \multicolumn{2}{c}{ Downy mildew severity 2014 } & \multicolumn{2}{c}{ Downy mildew severity 2015 } \\
\cline { 2 - 5 } & F value & Pr $>\mathrm{F}$ & F value & $\operatorname{Pr}>\mathrm{F}$ \\
\hline Treatments & 28.49 & $<0.0001^{*}$ & 4.91 & $0.0029^{*}$ \\
Phenological periods & 0.00 & $0.9972^{\mathrm{NS}}$ & 21.05 & $<0.0001^{*}$ \\
Treatments x Phenological periods & 0.08 & $0.9997^{\mathrm{NS}}$ & 0.16 & $0.9948^{\mathrm{NS}}$ \\
\hline
\end{tabular}

*, significant at $\mathrm{p} \leq 0.05 ; \mathrm{NS}$, non-significant at $\mathrm{p}>0.05$.

Table 4. Orthogonal contrasts of mean severity for phenological periods. Summer-fall crop season 2015.

\begin{tabular}{lcc}
\hline \multirow{2}{*}{ Contrasts $^{1}$} & \multicolumn{2}{c}{ Summer-fall crop season 2015 } \\
\cline { 2 - 3 } & F value & Pr $>$ F \\
\hline FL-FS vs. (FS-BR, BR-HA) & 41.88 & $<0.0001^{*}$ \\
FS-BR vs. BR-HA & 2.63 & $<0.1224^{\mathrm{NS}}$ \\
\hline
\end{tabular}

${ }^{1} \mathrm{FL}-\mathrm{FS}=$ Flowering to fruit set; FS-BR $=$ Fruit set to beginning of ripening; BR-HA = Beginning of ripening to harvest

*significant at $\mathrm{p} \leq 0.05 ; \mathrm{NS}$, non-significant at $\mathrm{p}>0.05$.

The summer-fall crop seasons showed higher frequencies of rainy days and higher daily minimum temperatures compared to the winter-spring crop seasons (Figure 3). In the summer-fall crop season of $2015829.7 \mathrm{~mm}$ of rainfall was recorded within a period of 52 days. Moreover, precipitation was recorded at $754.4 \mathrm{~mm}$ over 41 days in 2014 (Figures $3 \mathrm{c}$ and $3 \mathrm{~d})$. High humidity and temperatures above $18^{\circ} \mathrm{C}$ are considered major epidemiological factors determining downy mildew epidemics in northern Paraná (TESSMANN et al., 2007). In fact, growth and sporulation of $P$. viticola occurs at temperatures of $18^{\circ}$ to $25^{\circ} \mathrm{C}$, and temperature is responsible for accelerating or slowing the development of the disease (TAVARES et al., 2000; SÔNEGO et al., 2005).
Disease severity in convencional treatments did not differ from severity in treatments with sprayings made every seven and 14 days during the summerfall crops in both years. Similarly, the effects of these treatments did not differ significantly and resulted in intermediate disease severities when compared to the control and to spraying after observing the first symptoms of oil spots (Table 5, Figure 2). Despite the greater disease severity found in these treatments, this fact did not result in severity index to grape bunches (Table 2). Both summer-fall crop seasons showed different outcomes between the control and spraying after observing the first symptoms of oil spots. The severity of downy mildew in such treatments had significant differences during the summer-fall crop seasons of 2014, but the latter crop (2015) did not differ significantly (Table 5, Figure 2). 
Figure 3. Minimum, average and maximum air temperature $\left({ }^{\circ} \mathrm{C}\right)$, and rainfall $(\mathrm{mm})$ in winter spring crops in 2013 (a), 2014 (b) and in the summer-fall crops seasons of 2014 (c) and 2015 (d).

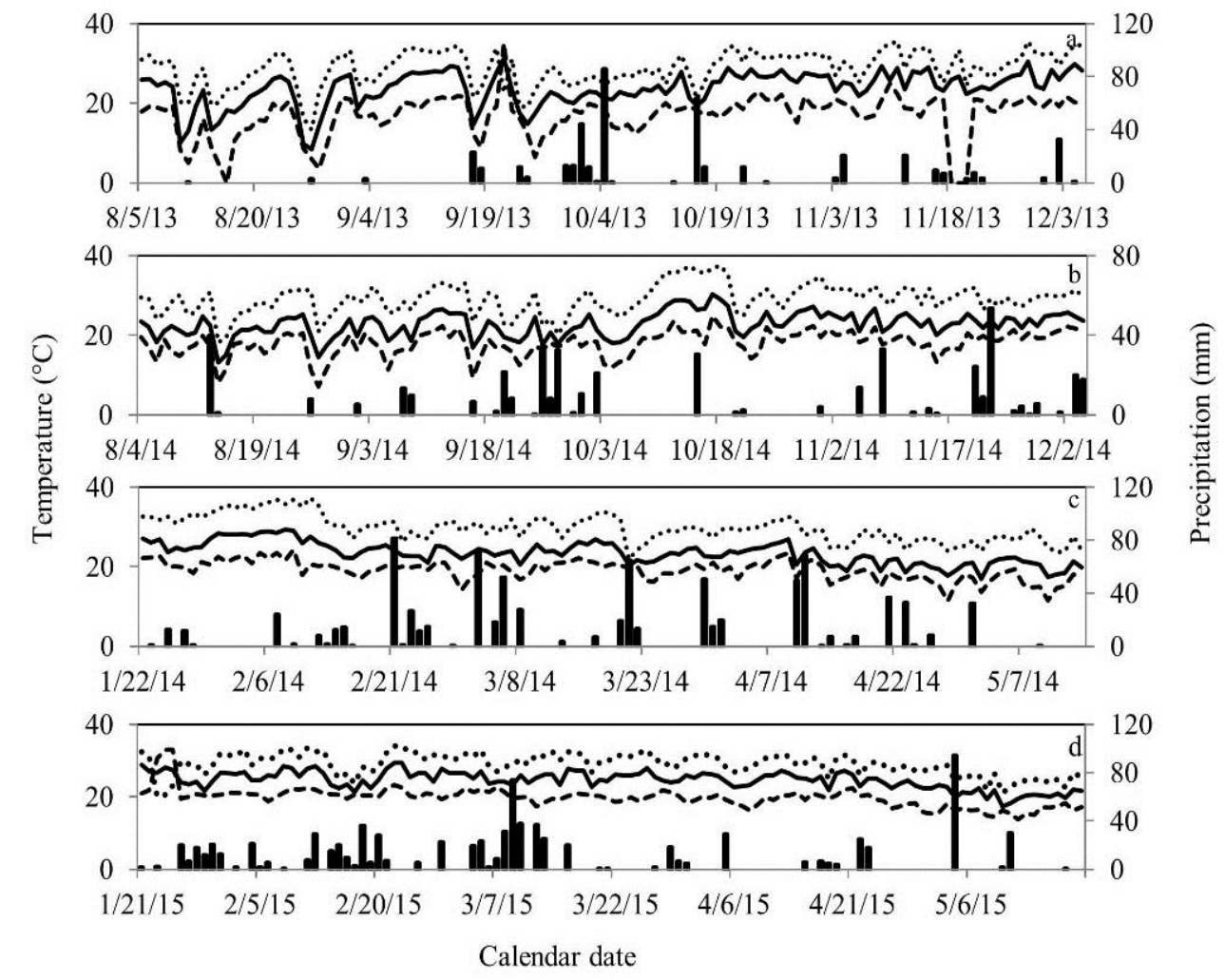

Table 5. Orthogonal contrasts of mean severity during the summer-fall crop seasons of 2014 and 2015.

\begin{tabular}{lcccc}
\hline \multirow{2}{*}{ Contrasts $^{1}$} & \multicolumn{2}{c}{2014} & \multicolumn{2}{c}{2015} \\
\cline { 2 - 5 } & F value & $\operatorname{Pr}>\mathrm{F}$ & $\mathrm{F}$ value & $\operatorname{Pr}>\mathrm{F}$ \\
\hline CONV vs. (S+7, S+14) & 0.42 & $0.5233^{\mathrm{NS}}$ & 1.84 & $0.1839^{\mathrm{NS}}$ \\
(S+7, S+14) vs. (S_O, CONTROL) & 94.53 & $<0.0001^{*}$ & 11.90 & $<0.0014^{*}$ \\
S+7 vs. S+14 & 3.31 & $0.0772^{\mathrm{NS}}$ & 0.71 & $0.4052^{\mathrm{NS}}$ \\
S_O vs. CONTROL & 10.53 & $<0.0025^{*}$ & 0.32 & $0.5751^{\mathrm{NS}}$ \\
\hline
\end{tabular}

${ }^{1} \mathrm{CONV}=$ conventional; $\mathrm{S}+7=$ spray every seven days; $\mathrm{S}+14=$ spray every 14 days and $\mathrm{S} \_\mathrm{O}=$ spraying after observation of the first downy mildew symptoms.

*significant at $\mathrm{p} \leq 0.05 ; \mathrm{NS}$, non-significant at $\mathrm{p}>0.05$.

The number of sprayings were higher in the summer-fall crop season of 2015 as compared to 2014 since climatic factors strongly associated with outbreaks occurred at higher frequencies that year (Table 2). In northern Paraná, grape producers have been using fewer sprayings than the standard treatment for 'BRS-Vitória', approximately 28-32 sprays, compared to the treatment of 'BRS Clara', a susceptible cultivar to downy mildew, that requires approximately 45-50 sprays in summer-fall crop season as reported by Genta et al. (2010). Attempts to reduce the number of fungicide applications for table grape cultivars in the region was performed by Abi Saab et al. (2002), where the goal was to increase the efficiency of control based on the quality of the fungicide application; however, they were unsuccessful in achieving this goal. 
Epidemiological and control studies about the influence of climatic factors on the progress of downy mildew of grapes, as well as the epidemiology of this disease, are limited in Brazil. Genta et al. (2010) evaluated if the effectiveness of plasticulture compared to the conventional anti-hail screen system for 'BRS Clara' seedless table grape in northern Paraná. The results showed that using a plastic cover caused a reduction in the number of fungicidal sprays used by $75 \%$ compared to the effect of using an anti-hail screen. Although plasticulture provides protection for plants against the occurrence of fungal diseases, it has high implementation costs. Another disadvantage reported by Pedro Júnior et al. (2011) relates to the high levels of fungicide in bunches that causes a depreciation in the quality of the grapes. This fact corroborates Chavarria and Santos (2009) in terms of the higher residual period of fungicides in greenhouses compared to period observed with conventional mechanisms, which implies the different mechanisms of controlling the disease.

This study presented evidences that 'BRS Vitória' in Paraná is less dependent on the use of fungicides. The use of resistant, immune or tolerant cultivars represents the ideal method for controlling plant diseases since it does not directly increase the cost of production and presents no environmental or human health risks (BERGAMIN FILHO; AMORIM, 1996). Thus, the information generated by is a contribution for the establishment of a more sustainable table grape production system in northern Paraná.

\section{Conclusions}

Downy mildew of grapes was more severe in the summer-fall crop seasons (January to May) than in the winter spring cropping season (August to December). The highest occurrence of the disease in summer-fall was associated to higher frequencies of rainy days and higher daily minimum temperatures. Severity index on bunches was not observed in any of the cropping seasons. The seedless grape 'BRS
Vitória' is less dependent on the use of fungicides to control downy mildew in northern Paraná, once disease severity in conventional treatments (sprays performed two or three times per week) did not differ from severity in treatments with sprayings made every seven and 14 days during the summerfall crops in both years.

\section{Acknowledgments}

The Coordination of Higher Education Personnel (CAPES), for granting a master's level scholarship to the first author.

\section{References}

ABI SAAB, O. J. G.; ANTUNIASSI, U. R.; FONSECA, I. C. de B.; GENTA, W.; BATISTELA, M. Efeito do tamanho de gota e volume de aplicação na deposição de agrotóxicos em folhas de videiras. Semina: Ciências Agrárias, Londrina, v. 23, n. 2, p. 221-228, 2002.

ANZANELlO, R.; SOUZA, P. V. D.; COELHO, P. F. Uso de poda seca e da poda verde para obtenção de duas safras por ciclo vegetativo em três cultivares de videira. Revista Brasileira de Fruticultura, Jaboticabal, v. 32, n. 1, p. 196-203, 2010.

BERGAMIN FILHO, A.; AMORIM, L. Doenças de plantas tropicais: epidemiologia e controle econômico. São Paulo: Agronômica Ceres, 1996. 289 p.

BUFFARA, C. R. S.; ANGELOTTI, F.; VIEIRA, R. A.; BOGO, A.; TESSMANN, D. J.; BEM, B. P. D. Elaboration and validation of a diagrammatic scale to assess downy mildew severity in grapevine. Ciência Rural, Santa Maria, v. 44, n. 8, p. 1384-1391, 2014.

CAVIGLIONE, J. H.; KIIHL, L. R. M.; CARAMORI, P. H.; OLIVEIRA, D. Cartas climáticas do Paraná. Edição 2000, versão 1.0. Londrina: Instituto Agronômico do Paraná, 2000. CD-ROM.

CHAVARRIA, G.; SANTOS, H. P. dos. Manejo de videiras sob cultivo protegido. Ciência Rural, Santa Maria, v. 39, n. 6, p. 19171924, 2009.

GENTA, W.; TESSMANN, D. J.; ROBERTO, S. R.; VIDA, J. B.; COLOMBO, L. A.; SCAPIN, C. R.; RICE, W. S.; CLOVIS, L. R. Manejo de míldio no cultivo protegido de videira de mesa BRS Clara. Pesquisa Agropecuária Brasileira, Brasília, v. 45, n. 12, p. 13881395, 2010. 
KISHINO, A. Y.; CARVALHO, S. L. C.; ROBERTO, S. R. Viticultura tropical: o sistema de produção do Paraná. Londrina: IAPAR, 2007. 366 p.

MAIA, J. D. G.; RITSCHEL, P. S.; CAMARGO, U. A.; SOUZA, R. T. de; FAJARDO, T. V. M.; NAVES, R. de L.; GIRARDI, C. L. BRS Vitoria: a novel seedless table grape cultivar exhibiting special flavor and tolerance to downy mildew (Plasmopara viticola). Crop Breeding and Applied Biotechnology, Viçosa, MG, v. 14, n. 3, p. 204-206, 2014.

McKINNEY, H. H. Influence of soil, temperature and moisture on infection of wheat seedlings by Helminthosporium sativum. Journal of Agricultural Research, Washington, v. 26, n. 26, p. 195-217, 1923.

PEARSON, R. G.; GOHEEN, A. C. Compendium of grape diseases. Saint Paul: American Phytopathological Society, 1988. 93 p.

PEDRO JÚNIOR, M. J.; HERNANDES, J. L.; ROLIM, G. S. Sistema de condução em Y com e sem cobertura plástica: microclima, produção, qualidade do cacho e ocorrência de doenças fúngicas na videira Niágara Rosada. Bragantia, Campinas, v. 70, n. 1, p. 228-233, 2011.

PRATT, C. Grapevine structure and growth stages. In: PEARSON, R. C.; GOHEEN, A. C. (Ed.). Compendium of grape diseases. Minnesota: APS, 1988. p. 3-7.
SHIMANO, I. S. H.; SENTELHAS, P. C. Risco climático para ocorrência de doenças fúngicas da videira no Sul e Sudeste do Brasil. Revista Ciência Agronômica, Fortaleza, v. 44, n. 3, p. 527-537, 2013.

SÔNEGO, O. R. Considerações sobre o controle químico da videira. Bento Gonçalves: Embrapa CNPUV, 1998. 4 p.

SÔNEGO, O. R.; GARRIDO, L. R.; GRIGOLETTI JÚNIOR, A. Principais doenças fúngicas da videira no sul do Brasil. Bento Gonçalves: EMBRAPA Uva e Vinho, 2005. 25 p. (Circular técnica, 56).

STATISTICAL ANALYSIS SYSTEM - SAS Institute. User's Guide. Cary: SAS Institute Inc., 2003. 129 p.

TAVARES, S. C. C. H.; LIMA, M. F.; MELO, N. F. Principais doenças da videira e alternativas de controle. In: LEÃO, P. C. de S.; SOARES, J. M. (Ed.). A viticultura no Semi-Árido Brasileiro. Petrolina: EMBRAPA SemiÁrido, 2000. p. 246-296.

TESSMANN, D. J.; VIDA, J. B.; GENTA, W.; KISHINO, A. Y. Doenças e seu manejo. In: KISHINO, A. Y.; CARVALHO, S. L. C.; ROBERTO, S. R. (Org.). Viticultura tropical: o sistema de produção do Paraná. Londrina: Instituto Agronômico do Paraná, IAPAR, 2007. p. 25-293. 